\title{
U-Pb zircon geochronology of volcanic deposits from the Permian basin of the Orobic Alps (Southern Alps, Lombardy): chronostratigraphic and geological implications
}

\author{
FABRIZIO BERRA*†, MASSIMO TIEPOLO $\ddagger$, VALERIA CAIRONI* \\ \& GIAN BARTOLOMEO SILETTO \\ * Università degli Studi di Milano, Dipartimento di Scienze della Terra A. Desio, Via Mangiagalli 34, 20133 Milan, \\ Italy \\ ‡C.N.R. - Istituto di Geoscienze e Georisorse, U.O.S. di Pavia, Via Ferrata 1, 27100 Pavia, Italy \\ $\S$ Regione Piemonte
}

(Received 19 February 2014; accepted 8 July 2014; first published online 15 September 2014)

\begin{abstract}
U-Pb zircon ages from volcanic rocks of Early Permian age (Southern Alps, Lombardy), associated with fault-controlled transtensional continental basins, were determined with the laser ablation (LA)-ICP-MS technique. Four samples were collected at the base and at the top of the up to $1000 \mathrm{~m}$ thick volcaniclastic unit of the Cabianca Volcanite. This unit pre-dates the development of a sedimentary succession that still contains, at different stratigraphic levels, volcanic intercalations. Age results from a tuff in the basal part of the unit constrain the onset of the volcanic activity to $280 \pm 2.5$ Ma. Ignimbritic samples from the upper part of the unit show a large scatter in the age distribution. This is interpreted as the occurrence of antecrystic and autocrystic zircons. The youngest autocrystic zircons (c. $270 \mathrm{Ma}$ ) are thus interpreted as better constraining the eruption age, constraining the duration of the volcanic activity in the Orobic Basin to about $10 \mathrm{Ma}$. The new geochronological results compared with those of other Early Permian basins of the Southern Alps reveal important differences that may reflect (1) a real time-transgressive beginning and end of the volcanic activity or (2) the complex mixing of antecrystic and autocrystic zircon populations in the analysed samples.
\end{abstract}

Keywords: zircon, radiometric dating, Early Permian stratigraphy, Southern Alps.

\section{Introduction}

In the case of poorly fossiliferous or completely unfossiliferous sedimentary successions, radiometric dating of volcanic layers represents an important tool for defining the age of geological events and for the correlation of physically separated successions. The most favourable condition for using radiometric dating in sedimentary successions is when volcanic deposits intercalate in a sedimentary succession at different stratigraphic positions. Under the assumption that the volcanic eruption is temporally very close to the crystallization of the dated minerals, radiometric dating indirectly provides the age of the sediments containing the volcanic layers. This in turn permits constraining the tectonic and sedimentary evolution of the studied succession.

Radiometric dating can be performed on different types of minerals, following different procedures. Zircon is one of the most stable minerals in volcanic rocks and frequently occurs as an accessory mineral. Its dating via the $\mathrm{U}-\mathrm{Pb}$ isotope system either with bulk (e.g. isotope dilution thermal ionization mass spectrometry (ID-TIMS)) or microanalytical techniques (secondary ion mass spectrometry (SIMS) or laser ablation inductively coupled plasma mass spectrometry (LAICP-MS)) is usually the most used radiometric approach. Microanalytical techniques usually require a large number of analyses (statistically processed) on single crystals from a single sample and give ages with lower precision and accuracy than ID-TIMS. However, in the case of zircons with a complex growth history, they allow complete age patterns to be resolved. 
The accurate reconstruction of the time scale of the volcanic deposits within a sedimentary succession is, however, dependent on the correct interpretation of radiometric results, independent of the analytical technique used. This is a critical point, because, especially with microanalytical techniques, the distribution of analytical data from a single sample is frequently not unimodal (e.g. Quick et al. 2009; Sinigoi et al. 2011; Gretter et al. 2013): data derived from different crystals (i.e. the dispersion of ages from different crystals from the same sample or from different parts - cores versus rims - of the same crystal) must be carefully processed in order to confidently define the age of the sample.

The presence of scattered ages (if analytical errors or modification of the system after the rock forming process is excluded) can be related to the presence of antecrystic (zircon crystals that crystallized from an earlier pulse of magma but are incorporated in a later pulse; Miller et al. 2007) or xenocrystic zircons from much older to slightly older materials contaminating the magma. Inherited zircon cores are generally easily distinguished by being clearly older and/or by changes in the growth mode of the crystals. Antecrystic zircons are more difficult to recognize and their presence should be highlighted by bi- or poly-modal distributions of ages. The identification of zircon crystals related to a single magma pulse (i.e. autocrysts sensu Miller et al. 2007, who suggested using this term instead of the term phenocryst, as it carries a textural connotation) is thus mandatory for the interpretation of scattered age data. When xenocrystic, antecrystic and autocrystic zircons occur and the identification of multiple populations is not straightforward, important constraints on the interpretation of the analytical results are provided by the stratigraphic position (i.e. relative age) of the analysed samples.

A favourable scenario for the study of proximal volcanic deposits interfingering with sediments is represented by the Lower Permian succession of the Southern Alps. During Early Permian time, the future Southern Alps were characterized by the presence of several fault-controlled and physically separated sedimentary basins, where thick successions of poorly fossiliferous clastic continental deposits containing volcanic layers (mainly rhyolitic and rhyodacitic; e.g. Bargossi et al. 1998, 2000) accumulated. A significant number of radiometric zircon ages, obtained via various methods, have been collected in recent years from the major Permian basins of the Southern Alps (e.g. from the Collio Basin; Schaltegger \& Brack, 2007; Gretter et al. 2013; and the Tregiovo Basin and Bolzano Plateau; Marocchi etal.2008). However, for some of the major basins such as the Orobic Basin, reliable data are not yet available or scarce, thus preventing large-scale correlations.

Here we focus on the Cabianca Volcanite, and we carried out LA-ICP-MS zircon dating on volcanic rocks at the base and at the top of the succession. This allowed us to constrain the duration of the magmatic activity in the Orobic Basin and to discuss its bearing on the igneous activity of the other Permian basins in the Southern Alps.

\section{Geological setting}

During Early Permian time, after the Variscan orogeny, the future Alpine area was characterized by the development of several fault-controlled basins where thick successions of volcanic deposits and continental clastic sediments accumulated. In the Southern Alps, along an E-W section, different sedimentary basins are recognized (from the west, Fig. 1): the Lugano- Varese Basin, the Orobic Basin, the Val Trompia Basin, the Tregiovo Basin, the Athesian Volcanic Group and the Carnia Basins (Cassinis et al. 2000). The effusive Lower Permian deposits are the expression of major igneous activity in the Southern Alps documented at different crustal levels (Peressini et al. 2007), from the base of the crust (mafic complex in the Ivrea Verbano Zone) to the upper crust (granitic rocks in the Serie dei Laghi) and to subaerial conditions (ignimbritic flows and ashes in the Lower Permian sediments). Volcanic activity occurred between 290 Ma (intrusive bodies to the west of the Southern Alps) and $270 \mathrm{Ma}$ (effusive deposits) (Peressini et al. 2007; Schaltegger \& Brack, 2007; Marocchi et al. 2008; Quick et al. 2009). The development of the large-scale, silicic volcanism has recently been interpreted as a consequence of the intrusion of huge masses of mantle-derived basalt in the deep crust (Quick et al. 2009; Sinigoi et al. 2011). The geodynamic setting responsible for the development of the Permian basins and the related volcanic activity is still under debate. It has been attributed to: (1) late Variscan dextral wrenching that affected large parts of southern Europe (e.g. Arthaud \& Matte, 1977) due to the transition from Pangaea B to Pangaea A (e.g. Muttoni et al. 2003), which occurred along an E-W-trending mega-shear zone that is considered to run along the Variscan suture (Schaltegger \& Brack, 2007 and references therein); (2) post-collisional collapse of the Variscan belt (Malaveille et al. 1990); (3) the initial stages of Tethyan rifting (e.g. Winterer \& Bosellini, 1981; Siletto et al. 1993); and (4) back-arc basin development in the hanging wall of a W-directed subduction zone, affecting and stretching the underlying Hercynian-Variscan orogen (Doglioni, 1995). Independent of their origin (a combination of different processes cannot be excluded), these basins are characterized by an extensional component.

The Early Permian basins that were formed in the Alpine area are filled by complex successions of volcanic and clastic continental deposits (Cassinis et al. 2000): each basin is characterized by a different depositional architecture and 
by different ratios and stratigraphic relationships of the volcanic and clastic deposits. Some basins (i.e. Athesian Volcanic Group of the Bolzano Plateau) are characterized by a prevalence of volcanic (mainly ignimbritic) deposits (Bargossi et al. 1998). In other basins (e.g. Collio Basin) volcanic products irregularly alternate with continental clastic deposits during the whole depositional history (Cassinis et al. 1988), or occupy a specific stratigraphic position (Orobic Basin, where a lower part mainly consisting of ignimbritic flows is covered by prevailing sedimentary units; Cadel $e t$ al. 1996). The thicknesses of the successions and the sizes of these basins are highlyvariable:thethicknessofvolcanicrocksandsediments reaches a maximum of about $4000 \mathrm{~m}$ (Athesian basin; Marocchi et al. 2008), but on average it is around 1500-2000 m, stored in basins covering up to several hundreds of square kilometres (Cassinis et al. 2007).

The Orobic Basin (Fig. 1) is one of the largest Permian basins of the Southern Alps (DeSitter \& DeSitter Koomans, 1949; Casati \& Gnaccolini, 1967; Cadel et al. 1996). The base of the sedimentary succession, resting on Variscan metamorphic rocks, is characterized by fluvial, poorly sorted conglomerates(Conglomerato Basale) mostly consisting of quartz and metamorphic clasts sourced from the Variscan basement. The reduced and slightly variable thickness (from 0 to a few tens of metres) is ascribed to the existence of a peneplain mantled by this unit. The top of the Conglomerato Basale in the Central Southern Alps is characterized by a sharp contact with pyroclastic flows, which marks the base of the Cabianca Volcanites (previously referred to as the Lower Collio Formation). The thickness of the Cabianca Volcanite rapidly pinches out from more than $1000 \mathrm{~m}$ in the depocentre to a few tens of metres of volcaniclastic deposits towards the fault-controlled borders of the basin, where only the upper part of the Cabianca Volcanites (mainly consisting of welded tuffs) is present. In the depocentral area, the Cabianca Volcanite can be divided in three major units (Cadel et al. 1996): a lower volcanic unit (tuffs and ignimbritic flows); a middle unit consisting of alternating sediments

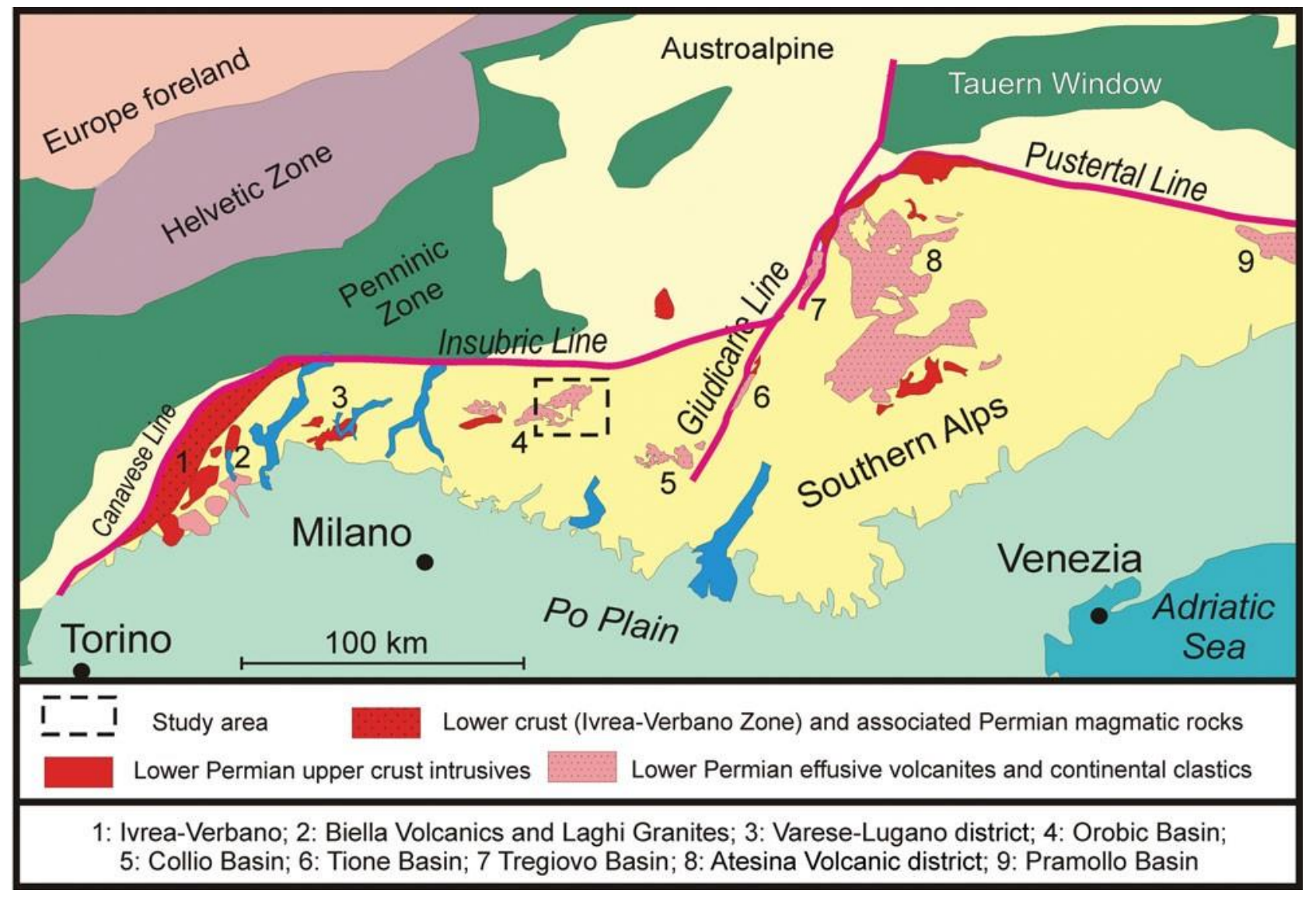

Figure 1. (Colour online) Geological setting of the Alpine belt, with the regional distribution of the Lower Permian sediments and volcanic sediments of the Southern Alps (modified after Berra \& Felletti, 2011).

(sandstones and siltstones) and pyroclastic deposits; and an upper unit, consisting mainly of ignimbritic flows (Cadel et al. 1996). The Cabianca Volcanite is covered by clastic sediments (in turn conglomerates, sandstones and siltstones) of the overlying Pizzo del Diavolo Formation (Cadel et al. 1996; Berra \& Felletti, 2011). This unit consists of various types of continental deposits: coarse conglomerates laterally evolve to thick sandstone bodies and, eventually, to dark siltstones locally characterized by intercalation of microbial carbonates. The distribution of these facies reflects coarse alluvial fans towards the fault-controlled borders of the basins, passing laterally to sandy flats and locally to playa lakes. Within this succession, tuff layers up to a few tens of metres thick are present. The top of the Pizzo del Diavolo 
Formation is marked by an angular unconformity at the boundary with the Verrucano Lombardo, recording a tectonic phase that marks the end of the deposition of the Lower Permian succession (Fig. 2).

The Orobic Basin is characterized by the local presence of important uranium deposits (mainly pitchblende as in the Val Vedello and Novazza mines; Cadel, 1986) that have been hydrothermally concentrated in two ignimbritic horizons in the middle part of the Cabianca Volcanite (Novazza) or along the contact between the basement and sedimentary cover (Val Vedello). The age of the uranium mineralization is problematic: according to poorly constrained radiometric dating (Philippe et al. 1987) it is Cretaceous, thus much younger than the age of the volcanic eruption.

Age constraints on the Permian succession of the Orobic Basin are scarce. The Cabianca Volcanite is bracketed between the unfossiliferous Conglomerato Basale and the poorly dated Pizzo del Diavolo Formation. The only available age on the Cabianca Volcanite is around $280 \mathrm{Ma}$ and was obtained on zircons from an ignimbritic flow in the Val Seriana zone by Philippe et al. (1987).

\section{Sampling positions and sites}

The base and the top of the Cabianca Volcanite have been sampled close to the depocentral area of the

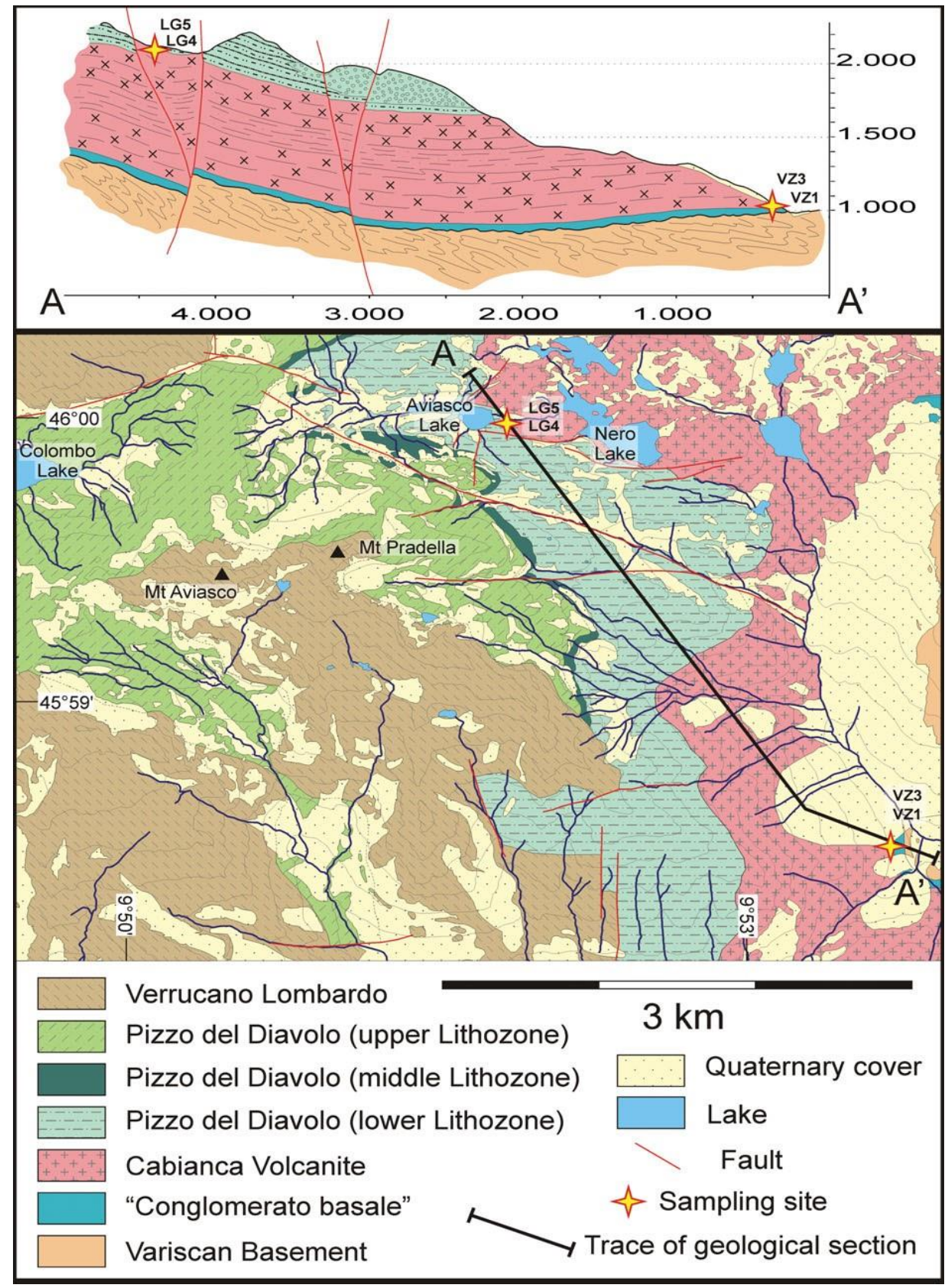


Figure 2. (Colour online) Geological map of the study area (modified after Berra \& Felletti, 2011) and geological section across the Lower Permian succession of the study area, with the position of the sampling sites. Gauss-Boaga coordinates for the collected samples are: LG4: 1.567.016/5.094.338; LG5: 1.567.011/5.094.330; VZ1: 1.569.379/5.091.440; VZ3: 1.569.355/5.091.421.
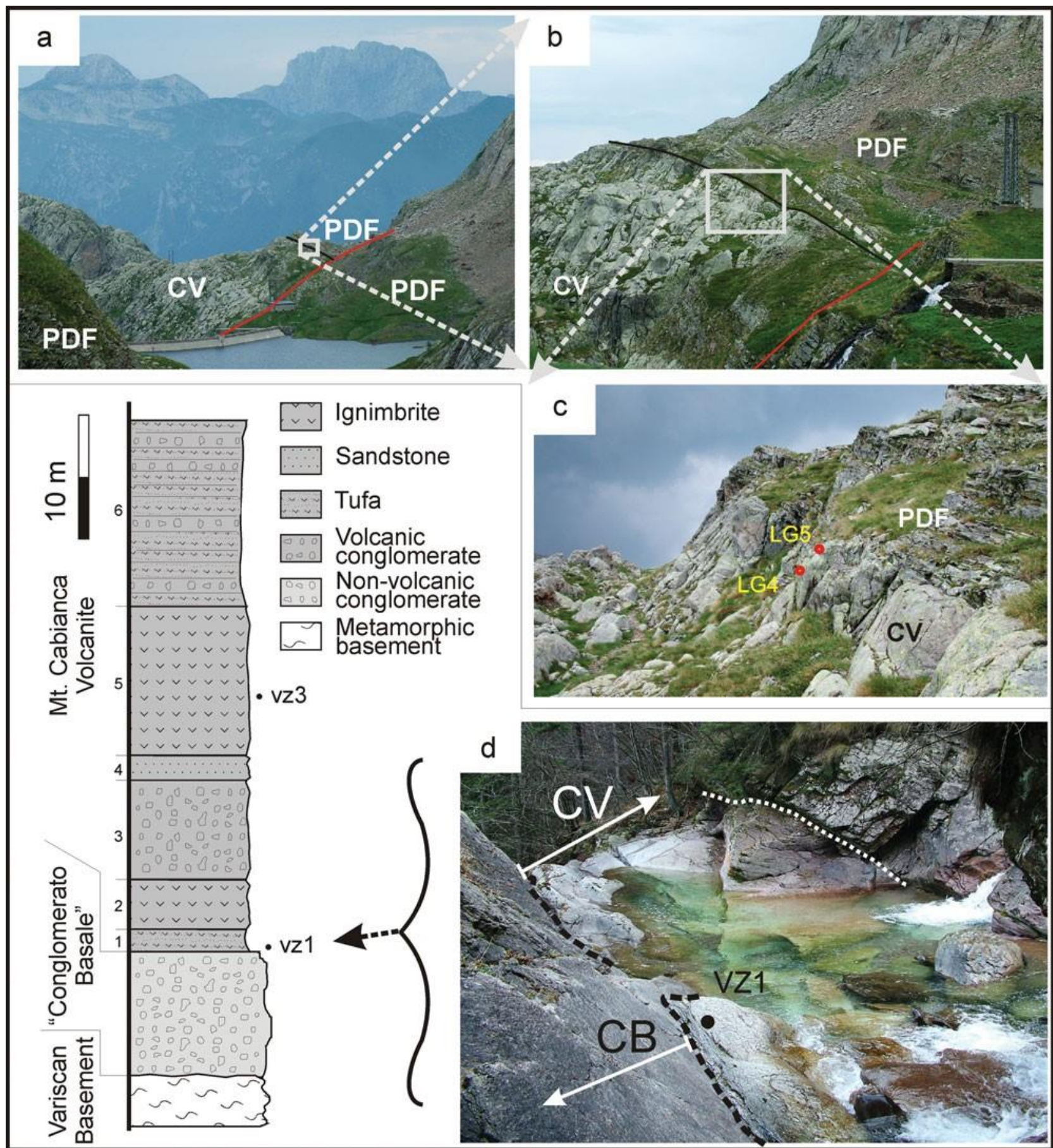

Ignimbrite
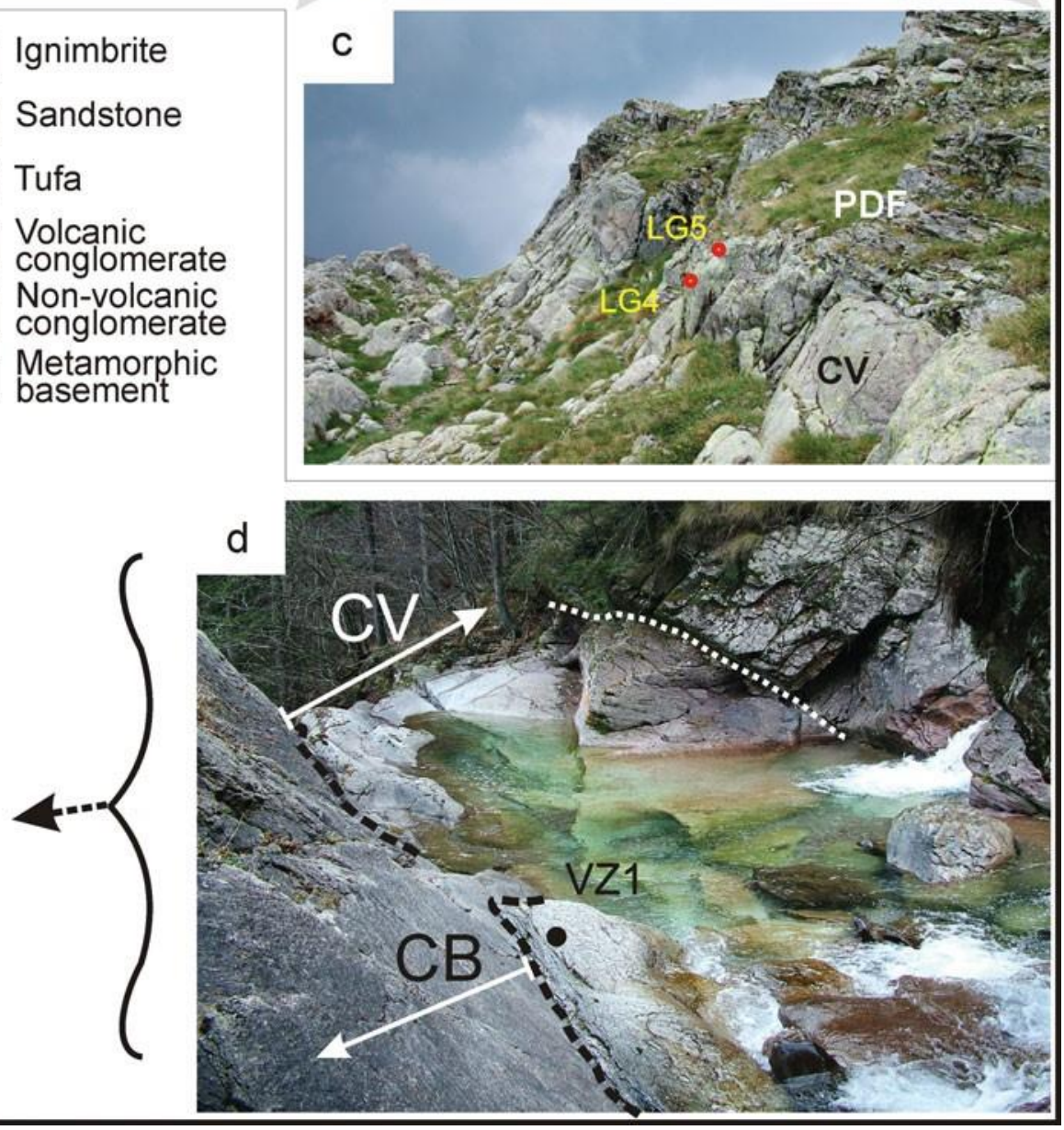

Figure 3. (Colour online) Position of the sampling sites at the top (a, b, c) and base (d) of the Cabianca Volcanite in the Orobic Basin: (a, b, c) position of the samples LG4 and LG5 at the top of the Cabianca Volcanite (CV), immediately below the base of the overlying prevalently sedimentary succession of the Pizzo del Diavolo Formation (PDF); (d) stratigraphic section (left) of the basal part of the Cabianca Volcanite (CV) where samples VZ1 and VZ3 were collected; on the right, view of the sharp contact between the aporphyric 'Conglomerato Basale' (CB) and the basal pyroclastic flows of the Cabianca Volcanite (CV) with the position of sample VZ1.

Orobic Basin (Cadel et al. 1996) (Fig. 2). Sampling was performed in order to define the beginning and the end of the interval of most intense volcanic activity in the basin. 
Two samples (VZ1 and VZ2) were collected from the base of the Cabianca Volcanite in Val Sanguigno, where a stratigraphic section in the basal part of the unit (from the top of the Conglomerato Basale) was measured (Fig. 3d). The lower sample (VZ1) represents the first ash flow above the Conglomerato Basale and thus is the oldest volcanic episode in the studied section. Sample VZ3 is from a massive ignimbritic flow (entirely consisting of volcanic components, lacking any metamorphic lithic clasts, but with abundant volcanic lithic clasts) about $20 \mathrm{~m}$ above the boundary with the Conglomerato Basale.

Samples LG4 and LG5 were collected in the uppermost part of the Cabianca Volcanite (Fig. 3a, b, c) from two different ignimbritic flows (entirely composed of volcanic material and without metamorphic lithic clasts) only about 2 $\mathrm{m}$ apart. In the uppermost few metres of the unit, thin beds of fine-grained sediments (siltstones, fine-grained sandstones) intercalate. The transition between the dominantly volcanic deposits (Cabianca Volcanite) and the Pizzo del Diavolo Formation is rapid (Fig. 3). In the study area, the base of the heterogenic Pizzo del Diavolo Formation consists of shales and siltstones, suggesting that deposition occurred close to the depocentre of the basin, which is bordered both northward and southward by coarser deposits in the same stratigraphic position (Berra \& Felletti, 2011).

\section{4. $\mathrm{U}-\mathrm{Pb}$ zircon geochronology}

\section{4.a. Methods}

For each of the four analysed samples 40 to 60 zircon crystals were separated with conventional methods (crushing, heavy liquids, hand picking). After the morphological characterization, zircons as free as possible from fractures and inclusions were mounted in epoxy resin, polished and internal structures characterized by cathodoluminescence (CL).

Zircons were dated at the C.N.R. Istituto di Geoscienze e Georisorse U.O.S. of Pavia using a GeoLas 200Q Microlas $193 \mathrm{~nm}$ excimer laser system equipped with a standard $20 \mathrm{~cm}^{3}$ ablation cell that was connected to a Thermo Finnigan Element I SF-ICP-MS instrument. Following 60 seconds of gas-blank acquisition, the sample was ablated for another 60 seconds in He. The laser was operated at $5 \mathrm{~Hz}$ using a spot size of $20 \mu \mathrm{m}$ and a laser fluence of $12 \mathrm{~J} \mathrm{~cm}$. Signalswereacquiredformasses202-204-206-207-208-232-238 using a scanning electron microscope (SEM) detector. Following the correction for gas-blank by onpeak subtraction, the laser induced elemental fractionation and mass bias of the ICP-MS were corrected for by normalizing the data to the 91500 reference zircon (Wiedenbeck et al. 1995). Given the relatively high background of $\mathrm{Hg}$, small amounts of common $\mathrm{Pb}$ cannot be detected. In all analysed samples ${ }^{204} \mathrm{~Pb}$ could not be discriminated from the background, and for this reason we did not apply any common $\mathrm{Pb}$ correction. Zircon reference sample 02123 (295 Ma, Ketchum et al. 2001) was analysed as an unknown in each analytical run and yielded a weighted mean (four analyses) ${ }^{206} \mathrm{~Pb}-{ }^{238} \mathrm{U}$ age of $295 \pm 5 \mathrm{Ma}(2 \sigma)$. Data reduction was carried out using the 'Glitter' software package (van Achterbergh et al. 2001). The reproducibility on the standards was propagated to all determinations according to the equation in Horstwood et al. (2003). After this operation, analyses are considered accurate within quoted errors. Concordia plots were constructed using the Isoplot/EX 3.0 software (Ludwig, 2000). All errors quoted in the text are given at the $2 \sigma$ level.

\section{4.b. Zircon structure and morphology}

The zircons show rather well-developed crystal morphology (see online Supplementary Material available at http://journal.cambridge.org/geo). In the ash flow sample VZ1 they have dimensions between 50 and $180 \mu \mathrm{m}$ and show well-developed faces and edges. Internal growth zoning was observed under CL (Figs 4, 5; see also online Supplementary Material available at http://journal.cambridge.org/geo). In most zircons from samples VZ3, LG4 and LG5, zoning patterns reflect the external morphology, suggesting a continuous growth process. Inherited domains were observed in only a few zircons. In zircons from sample VZ1 the zone profile gradually changes from a dominating 211 bipyramidal configuration to a dominating 101 bipyramidal configuration, suggesting a possible progressive magma compositional evolution during crystallization. No inherited domains were observed in sample VZ1.

\section{4.c. Age results}

Twenty of the 29 zircons analysed (Figs 4,6) in the basal tuff (sample VZ1) gave concordant dates, i.e. less than $2 \%$ difference between $206 \mathrm{~Pb}-238 \mathrm{U}$ and $207 \mathrm{~Pb}-235 \mathrm{U}$ ages. Zircon no. 20 gave unrealistically young $206 \mathrm{~Pb}-238 \mathrm{U}$ dates: $245 \pm 9 \mathrm{Ma}(2 \sigma)$ at the external rim of the crystal and $269 \pm 10 \mathrm{Ma}$ at the core. Most likely a late event has perturbed the $\mathrm{U}-\mathrm{Pb}$ system in this grain, at least in the external part, so that it has been discharged. The $264 \pm 12$ Ma date obtained from the external rim of crystal no. 2 has been disregarded for the same reason. The other concordant 206Pb-238U dates span 
between $291 \pm 10 \mathrm{Ma}$ and $272 \pm 10 \mathrm{Ma}$ with a weighted average $206 \mathrm{~Pb}-238 \mathrm{U}$ date of $280 \pm 2.5 \mathrm{Ma}(95 \%$ conf.; $\mathrm{MSWD}=$ $0.9)$.

Twenty-two of the 29 zircons analysed in the ignimbrite sample VZ3 (Figs 4,6) gave concordant dates. The 206 Pb$238 \mathrm{U}$ dates are mostly in the range of $279 \pm 12 \mathrm{Ma}$ to $300 \pm 12 \mathrm{Ma}$. Two analyses gave significantly different $206 \mathrm{~Pb}-$ $238 \mathrm{U}$ dates of $347 \pm 16 \mathrm{Ma}$ and $267 \pm 11 \mathrm{Ma}(2 \sigma)$. The $347 \pm 16 \mathrm{Ma}$ date is from the core of crystal no. 12 and is likely to represent inheritance. Remarkably, the rim of the same zircon is dated at $300 \pm 15 \mathrm{Ma}$, thus suggesting a new episode of crystallization before eruption. The $267 \pm 11$ Ma date is from the core of zircon no. 20 , which is nearly homogeneous and with faint oscillatory zoning. According to the zircon texture, we interpret this young $206 \mathrm{~Pb}-238 \mathrm{U}$ date to be poorly representative and likely affected by a late perturbation of the U-Pb system. The major age cluster yields a weighted average $206 \mathrm{~Pb}-238 \mathrm{U}$ date at $291 \pm 4 \mathrm{Ma}(95 \%$ conf.; MSWD $=1.2)$.

Eighteen of the 29 analysed zircons in the ignimbrite sample LG4 (Figs 5, 7) gave concordant dates. 206 Pb-238U concordant dates define a continuum from $264 \pm 8 \mathrm{Ma}$ up to $301 \pm 10 \mathrm{Ma}$. With the exception of three older dates that pertain to crystal cores apparently mantled by new zircons (crystal nos 9,13 and 35) and thus likely of xenocrystic origin, other dates have no clear relationship with the zircon texture. It is noteworthy that relatively homogenous and euhedral zircons yield both young and old dates. The age dispersion in this sample is well above the analytical uncertainty of the technique and does not allow calculating a statistically meaningful ${ }^{206} \mathrm{~Pb}-{ }^{238} \mathrm{U}$ average age.
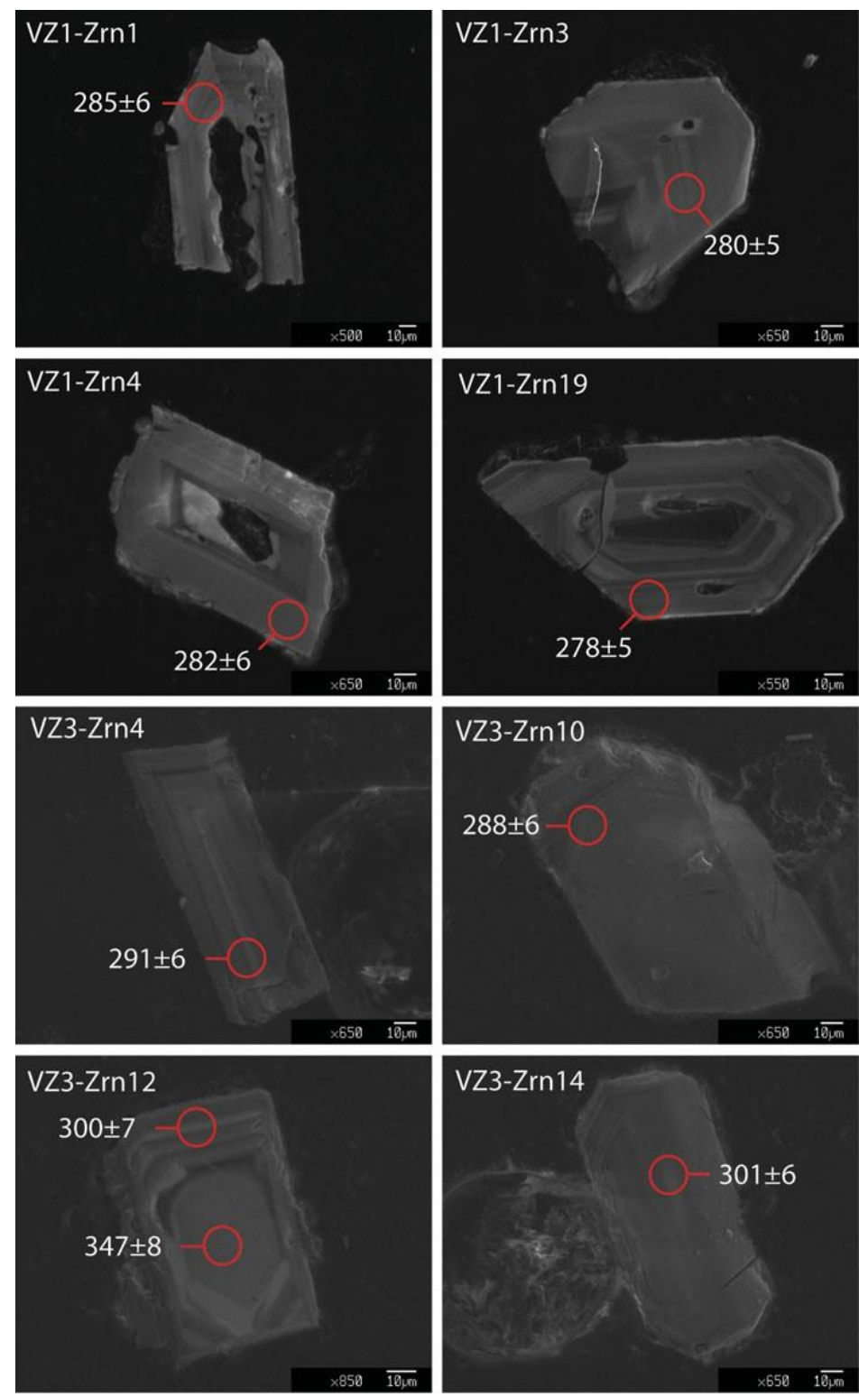

Figure 4. (Colour online) Cathodoluminescence images of selected zircons for the stratigraphically lower samples VZ1 and VZ3 with locations of the spot analyses (red circles). 
Twenty-three of the 29 zircons in the ignimbrite sample LG5 (Figs 5, 7) gave concordant results. ${ }^{206} \mathrm{~Pb}-{ }^{238} \mathrm{U}$ concordant dates, as in sample LG4, show a large scatter well above the analytical uncertainty of the technique. The age spectrum gives a continuum from $265 \pm 6 \mathrm{Ma}$ to $298 \pm 10 \mathrm{Ma}$. With the exception of the oldest age, obtained from a bright core of possible xenocrystic origin, all the other dates do not allow establishing a relationship with the zircon structure and do not allow calculating a statistically meaningful ${ }^{206} \mathrm{~Pb}-{ }^{238} \mathrm{U}$ average age. The analytical results for each crystal are reported in the online Supplementary Material available at http://journal.cambridge.org/geo.
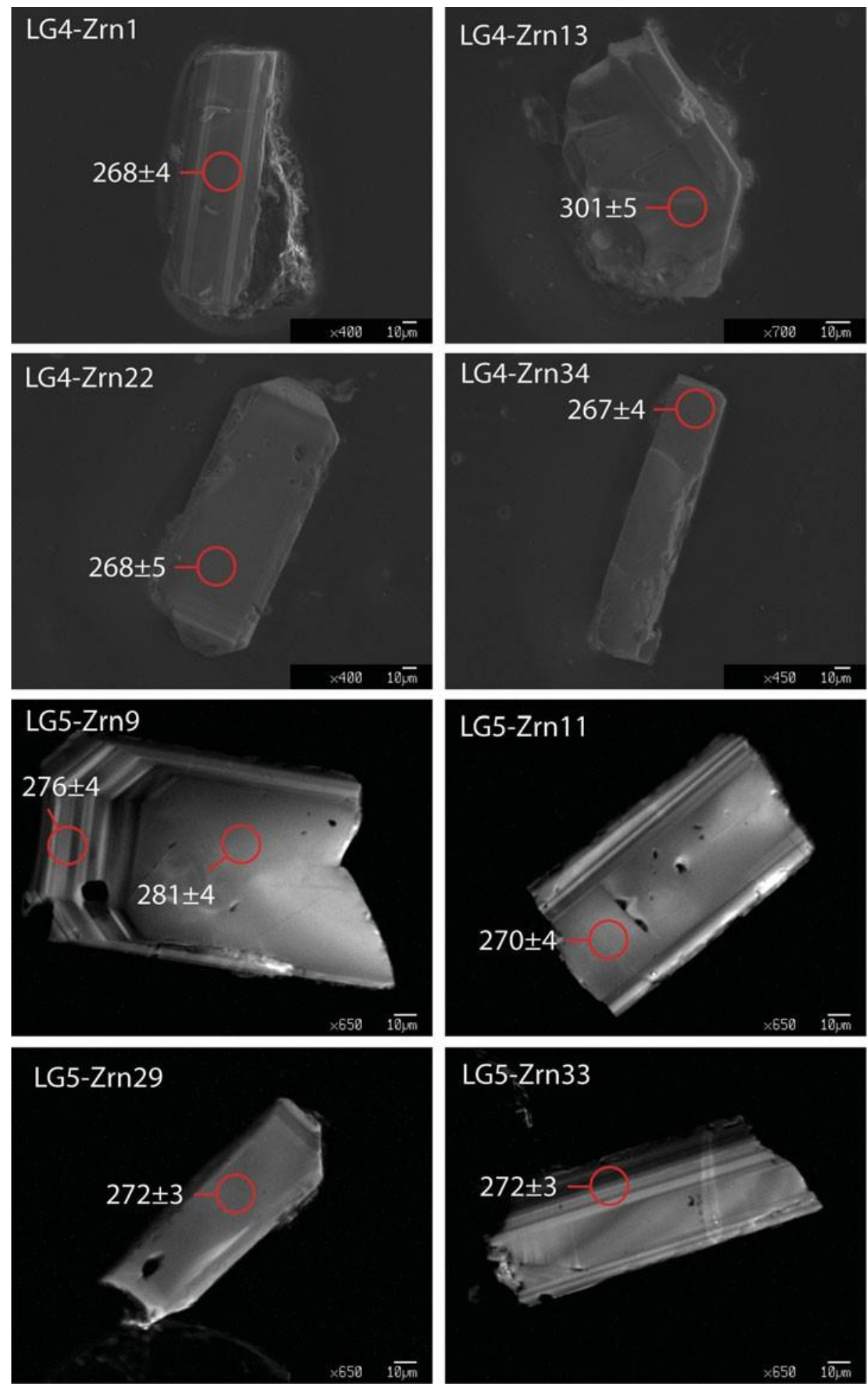

Figure 5. (Colour online) Cathodoluminescence images of selected zircons for the stratigraphically upper samples LG4 and LG5 with locations of the spot analyses (red circles). 


\section{Discussion}

\section{5.a. Zircon age interpretation}

The relatively large age distribution for most of the samples complicates the reconstruction of the timing of the events. In particular, considering each sample alone, age dispersion does not allow calculation of statistically meaningful ages for the uppermost samples. However, the well-defined stratigraphic position of samples robustly provides their relative age and gives important hints on radiometric data interpretation. The geological significance of the two calculated weighted average ${ }^{206} \mathrm{~Pb}-{ }^{238} \mathrm{U}$ dates in the basal samples is in fact questionable, as the age of the basal tuff VZ1 is approximately 10 Ma younger than the overlying VZ3 pyroclastic deposit.
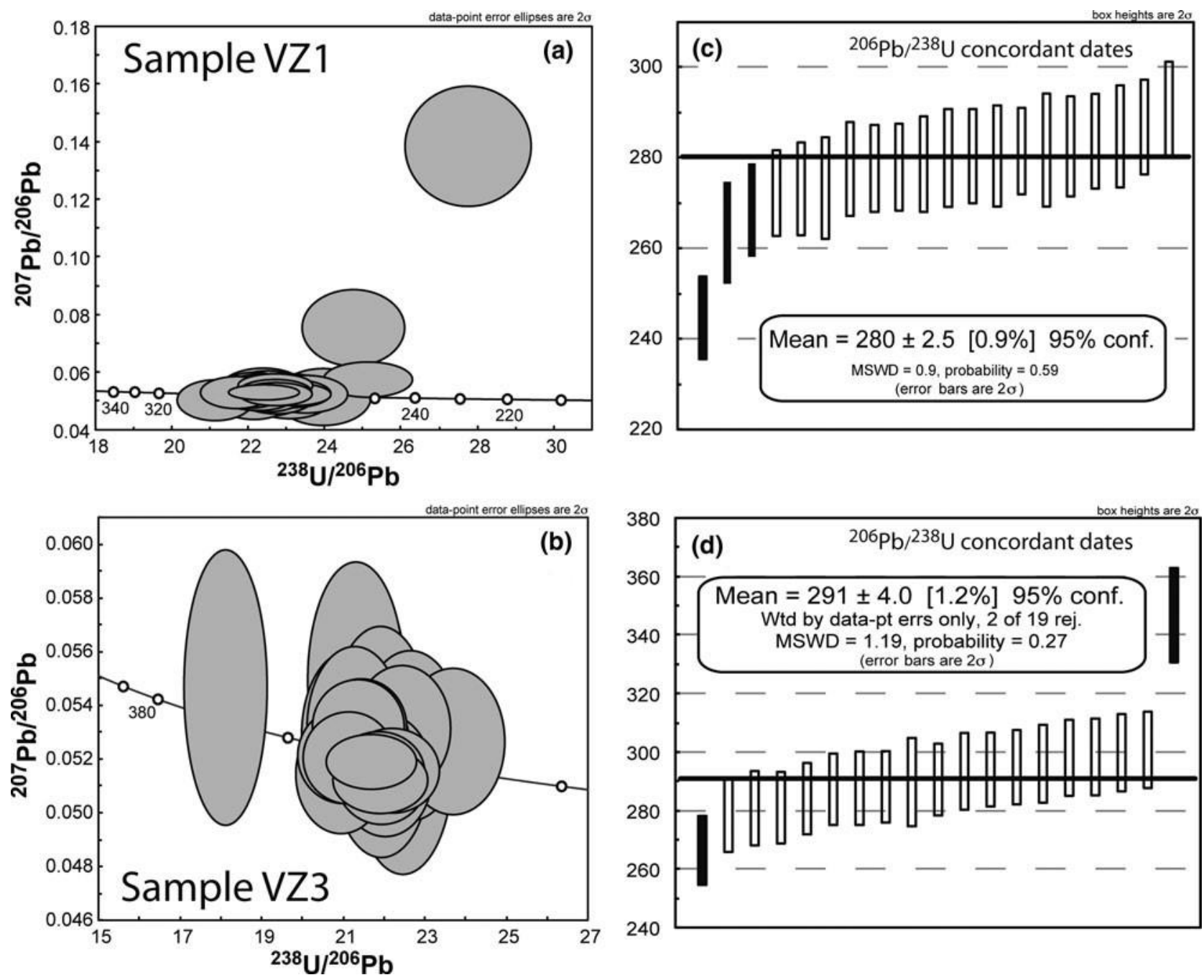

Figure 6. Geochronological results for the lowermost samples. (a, b) Tera-Wasserburg ${ }^{207} \mathrm{~Pb} /{ }^{206} \mathrm{~Pb}$ versus ${ }^{238} \mathrm{U} /{ }^{206} \mathrm{~Pb}$ diagrams for the lowermost samples VZ1 and VZ3. (c, d) Weighted average ${ }^{238} \mathrm{U}-{ }^{206} \mathrm{~Pb}$ concordant dates. Data in black were not considered in the calculation.

The basal tuff sample VZ1, containing zircons that generally better preserve the magmatic textures, has a lower age spread than sample VZ3. As a consequence, the weighted average date of $280 \pm 2.5 \mathrm{Ma}(95 \%$ conf.; MSWD $=0.9$ ) is considered the best approximation for the beginning of the magmatic activity in the Orobic Basin. Therefore, a discussion about the origin of the age spread in the layer containing sample VZ3 is important for the interpretation of its age of eruption. The $\mathrm{U}-\mathrm{Pb}$ date variations apparently have poor relationships with zircon textures: the youngest ages are not systematically at the rims of the zircon crystals and a clear mantle-core age variation characterizes only a few crystals. According to this evidence, age spread could be related to (i) variable $\mathrm{Pb}$ loss or to (ii) the presence of antecrystic and xenocrystic crystals very close in age and not discriminable by the analytical technique and/or morphological features.

$\mathrm{Pb}$ loss causes the shift of dates towards younger ages and, given the relatively large errors, concordance in the $\mathrm{U}-\mathrm{Pb}$ system could be preserved. According to this hypothesis, the oldest dates should be those better approximating the age 
of eruption. For sample VZ3 if we consider all the dates within $2 \sigma$ uncertainty, with the oldest dates the resulting weighted ${ }^{206} \mathrm{~Pb}-{ }^{238} \mathrm{U}$ average age is $294 \pm 4 \mathrm{Ma}(95 \%$ conf.; MSWD $=0.54)$.

Remarkably, this date is still geologically inconsistent, being older than that of the basal sample VZ1. The same approach applied to the samples from the top of the Cabianca Volcanite yields weighted ${ }^{206} \mathrm{~Pb}-{ }^{238} \mathrm{U}$ average ages of $281 \pm 4 \mathrm{Ma}(95 \%$ conf.; MSWD $=0.93$ ) for the LG4 sample and $283 \pm 3 \mathrm{Ma}(95 \%$ conf.; MSWD $=0.55$ ) for sample LG5. Pb loss can be ascribed to hydrothermal events, well-documented processes in the Permian igneous and metamorphic units of the Ivrea Verbano Zone (e.g. Vavra, Schmid \& Gebauer, 1999; Harlov \& Wirth, 2000; Peressini et al. 2007; Sinigoi et al. 2011; Ewing, Hermann \& Rubatto, 2013). Locally, hydrothermal circulation has certainly affected the Cabianca Volcanite as suggested by the presence of uranium deposits. However, studied samples were taken far (some kilometres to the east) from the uranium mineralization.
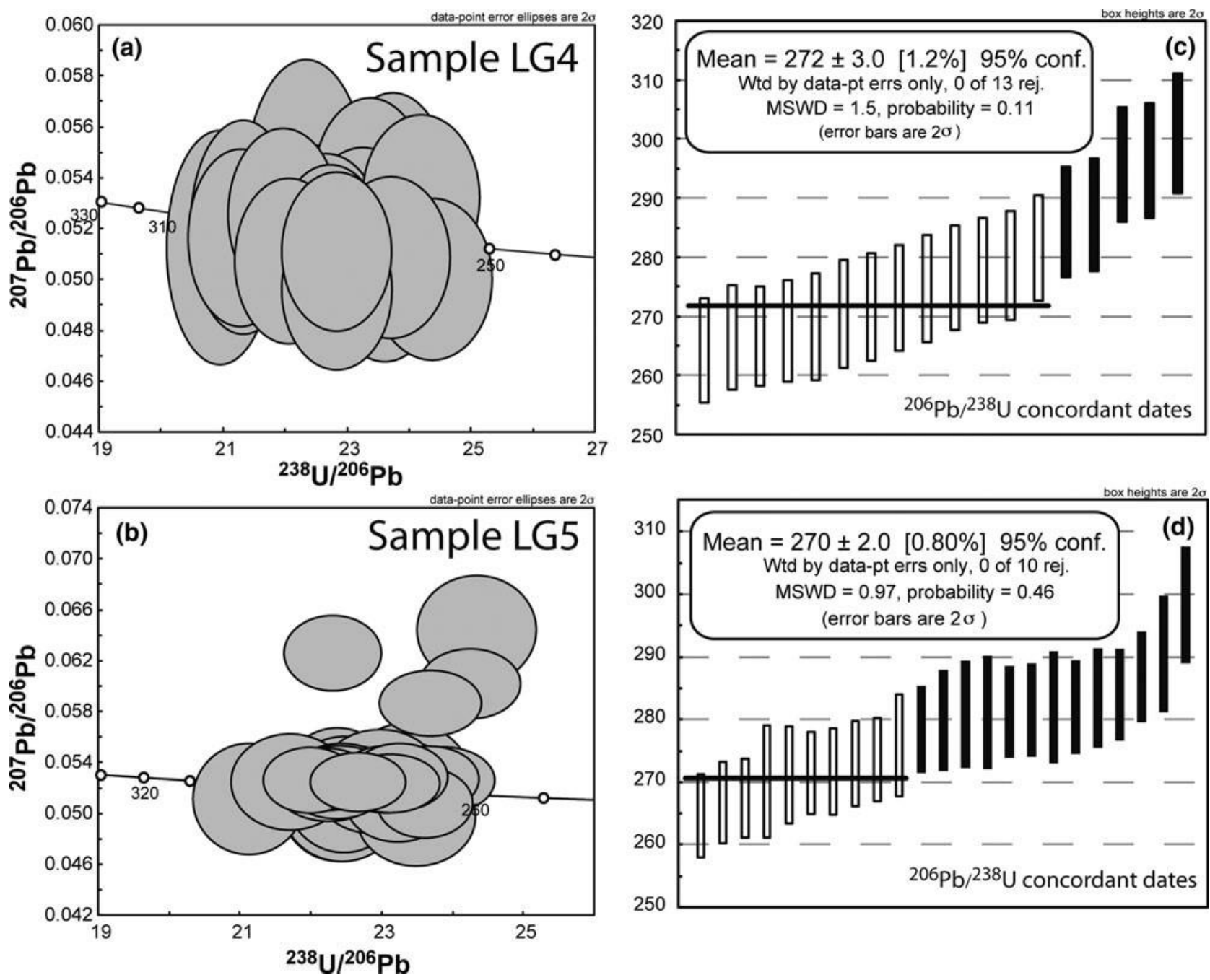

Figure 7. Geochronological results for the stratigraphically upper samples. (a, b) Tera-Wasserburg ${ }^{207} \mathrm{~Pb} /{ }^{206} \mathrm{~Pb}$ versus ${ }^{238} \mathrm{U} /{ }^{206} \mathrm{~Pb}$ diagrams for samples LG4 and LG5. (c, d) Weighted average ${ }^{238} \mathrm{U}-{ }^{206} \mathrm{~Pb}$ concordant dates. Data in black were not considered in the calculation.

No evidence of hydrothermal circulation or uranium mobilization is documented in the studied outcrops. Zircon texture also excludes recrystallization in the presence of fluids because the typical bright homogeneous overgrowths are lacking (Schaltegger et al. 1999; Corfu et al. 2003). Hydrothermal alteration is further unlikely because of the almost absence of Mesozoic ages in the analysed samples (only one crystal yields a Triassic age), as observed close to the uranium mineralizations (Philippe et al. 1987). Nonetheless, a possible reduced and partial U-Pb system perturbation, likely without growth of new zircons, may have occurred in the studied samples, as possibly suggested by the occurrence 
of a few very young zircons. Evaluating how much this process may have affected the other zircon grains is, however, not straightforward. In conclusion, under the hypothesis of a $\mathrm{U}-\mathrm{Pb}$ system perturbation, the onset and termination of the magmatic activity in the Orobic Basin could not be analytically discriminated and the entire Cabianca Volcanite was deposed at about $280 \mathrm{Ma}$.

Alternatively, the age scatter can be related to the presence of multiple zircon populations. This hypothesis would agree with the different natures of the sampled rocks. The basal sample VZ3 and the topmost samples LG4 and LG5 are ignimbrite flows and thus different in terms of volcanic processes from the tuff sample VZ1. Ignimbrite flows during both the explosive phase and deposition typically mobilize older material. Evidence of this process in the major ignimbritic flows of the Orobic Basin is the occurrence of abundant volcanic and metamorphic lithic clasts. Zircon crystals found in the studied ignimbritic samples may be thus a mixing of xenocrystic, antecrystic and autocrystic grains. Accordingly, the younger dates are those better approximating the age of eruption. With this approach, in the sample VZ3 the dates within $2 \sigma$ uncertainty with the youngest date yield a weighted ${ }^{206} \mathrm{~Pb}-{ }^{238} \mathrm{U}$ average age of $285 \pm 4 \mathrm{Ma}(95 \%$ conf.; MSWD = 0.47), compatible with those of the basal tuff (VZ1). In sample LG4 if all the dates within $2 \sigma$ uncertainty with the youngest date are considered, the weighted ${ }^{206} \mathrm{~Pb}-{ }^{238} \mathrm{U}$ average age is $272 \pm 3 \mathrm{Ma}$ (95\% conf.; MSWD = 1.5). Similarly, for sample LG5 the weighted ${ }^{206} \mathrm{~Pb}-{ }^{238} \mathrm{U}$ average age is $270 \pm 2 \mathrm{Ma}(95 \%$ conf.; MSWD $=0.97)$. Under the hypothesis of the presence of multiple zircon populations, dates spread over $c .10 \mathrm{Ma}$ separate the onset (c. $280 \mathrm{Ma})$ and the termination (c. $270 \mathrm{Ma}$ ) of the magmatic activity.

Considering that (i) the Pb loss hypothesis fails to explain the older age of sample VZ3 relative to the basal sample VZ1 and (ii) the coherent scenario obtained from the assumption that the younger ages better reflect the emplacement of the sampled beds, we suggest that the hypothesis of the co-presence of multiple zircon populations in a single sample better explains the obtained ages. In order to justify the inconsistency between the two basal samples, an extreme case of no presence of autocrysts in sample VZ3, i.e. a magma with no zircon saturation, should be supposed. Although possible, this event is unlikely for the relatively evolved nature of magmas constituting ignimbritic flows. Moreover, a progressive variation in the age of mobilized material is observed along the succession, thus contrasting with the $\mathrm{Pb}$ loss hypothesis. The ignimbrite flow in the lower part of the Cabianca Volcanite (VZ3) contains an important component from igneous rocks with ages in the time span 290-300 Ma. This component is also present, but less abundant, in the lower ignimbrite flow at the top of the succession (LG4) and is almost absent in the uppermost ignimbrite flow (LG5). In the latter, the xenocrystic/antecrystic component is substituted by zircons with prevalent ages of $280 \mathrm{Ma}$, coeval with the volcanic activity at the base of the succession (sample VZ1). This observation can be explained by the progressive covering by younger crystallized products of older rocks constituting the walls of the magma chamber (or of the conduits). Every new volcanic event would then mobilize and recycle different (in quantity and age) material from the older magmatic events, thus explaining the shift towards younger ages of the xenocrystic/antecrystic material and the gradual decrease in zircons of 290-300 Ma (up to their absence) in the latest ignimbrite products.

\section{5.b. Age of the volcanic activity in the Early Permian basins of the Southern Alps}

The stratigraphic architectures of the Permian basins of the Southern Alps record a period of intense tectonic and volcanic activity. The presence of volcanic layers alternating with continental sediments permits obtaining radiometric ages in the different basins (Fig. 8; time scale from Subcommission on Permian Stratigraphy, International Permian Time Scale, 2013). These basins were formed in Early Permian time, but a precise comparison between the time span covered by each basin is still controversial, as ages have been obtained with different methods and the interpretation could be ambiguous.

The available radiometric ages from the major basins (Orobic Basin, Val Trompia Basin, Tregiovo Basin, Athesian Volcanic Group) cluster in an age range from about $283 \mathrm{Ma}$ to $270 \mathrm{Ma}$. The age of the largest volcanic body of the Southern Alps, the Athesian Volcanic Group, is bracketed between about 285.4 $\pm 1.6 \mathrm{Ma}$ at the base and 274.2 $\pm 2.9 \mathrm{Ma}$ at the top (Bargossi et al. 2004; Marocchi et al. 2008). The succession of the Tregiovo Basin rests on a lower volcanic unit (the Monte Luco Formation, consisting of rhyodacitic lavas which were deposited between about $284.9 \pm 1.6 \mathrm{Ma}$ and $278.4 \pm 1.5 \mathrm{Ma}$; Marocchi et al. 2008), later covered by a mixed sedimentary and volcaniclastic succession that yields an age of $274.1 \pm 1.6 \mathrm{Ma}$ at the top (Marocchi et al. 2008). The stratigraphy of these two basins is similar, and the uppermost unit of the Tregiovo Basin (the Predonico Member of the Ora Formation) interfingers with the uppermost part of the Athesian Volcanic Group, so that the Tregiovo Basin can be considered strictly related to the Athesian Basin (Marocchi et al. 2008). The Val Trompia Basin yields slightly older results as its succession is dated to between 283.1 $\pm 0.6 \mathrm{Ma}$ and $279.8 \pm 1.1 \mathrm{Ma}$ (Schaltegger \&

Brack, 2007; Gretter et al. 2013).

The new ages obtained for the Orobic Basin confirm the existence of Permian volcanic activity in the Southern Alps around $290 \mathrm{Ma}$ (documented by antecrystic zircons, in agreement with the data from Val Sesia by Quick $e t$ 
al. 2009) and the eruption of volcanic deposits in the Orobic Basin around $280 \mathrm{Ma}$ (as in the Athesian Volcanic Group), but possibly suggest a more recent end (about $270 \mathrm{Ma}$ ) with respect to all the basins considered. The Cabianca Volcanite is covered by more than $1000 \mathrm{~m}$ of sediments (upper 'Collio' Formation, Cadel et al. 1996; Pizzo del Diavolo Formation; Berra \& Felletti, 2011): the age of this unit is poorly constrained, but its thickness and internal organization suggest a significant interval of time for its deposition, further rejuvenating the end of the deposition of the Lower Permian succession of the Orobic Basin with respect to the other basins of the Southern Alps (Fig. 8). The beginning of a major volcanic event in some of the basins of the Southern Alps seems to occur around $280 \mathrm{Ma}$ (an age obtained with different methods). The different age of the end of the major volcanic pulse (which in the Orobic Basin seems to last longer and to end later than in the other Permian basins of the Southern Alps) can be ascribed to three possible reasons: (1) perturbations of the system (i.e. Pb loss); this seems unlikely owing to the absence of geological evidence of hydrothermal circulation in the studied area and by the fact that most of the obtained ages are in tune with the major magmatic events in the Southern Alps, so that in this case we have to postulate unrealistic selective perturbations, (2) the end of the Early Permian effusive volcanic activity is significantly diachronous or (3) the available ages could be, at least partly, the product of zircons that are spread along the Concordia with overlapping individual error ellipses so that the obtained age could be (at least in some cases) the result of the coexistence in the same sample of different but unidentifiable zircon populations (antecrystic and autocrystic zircons).

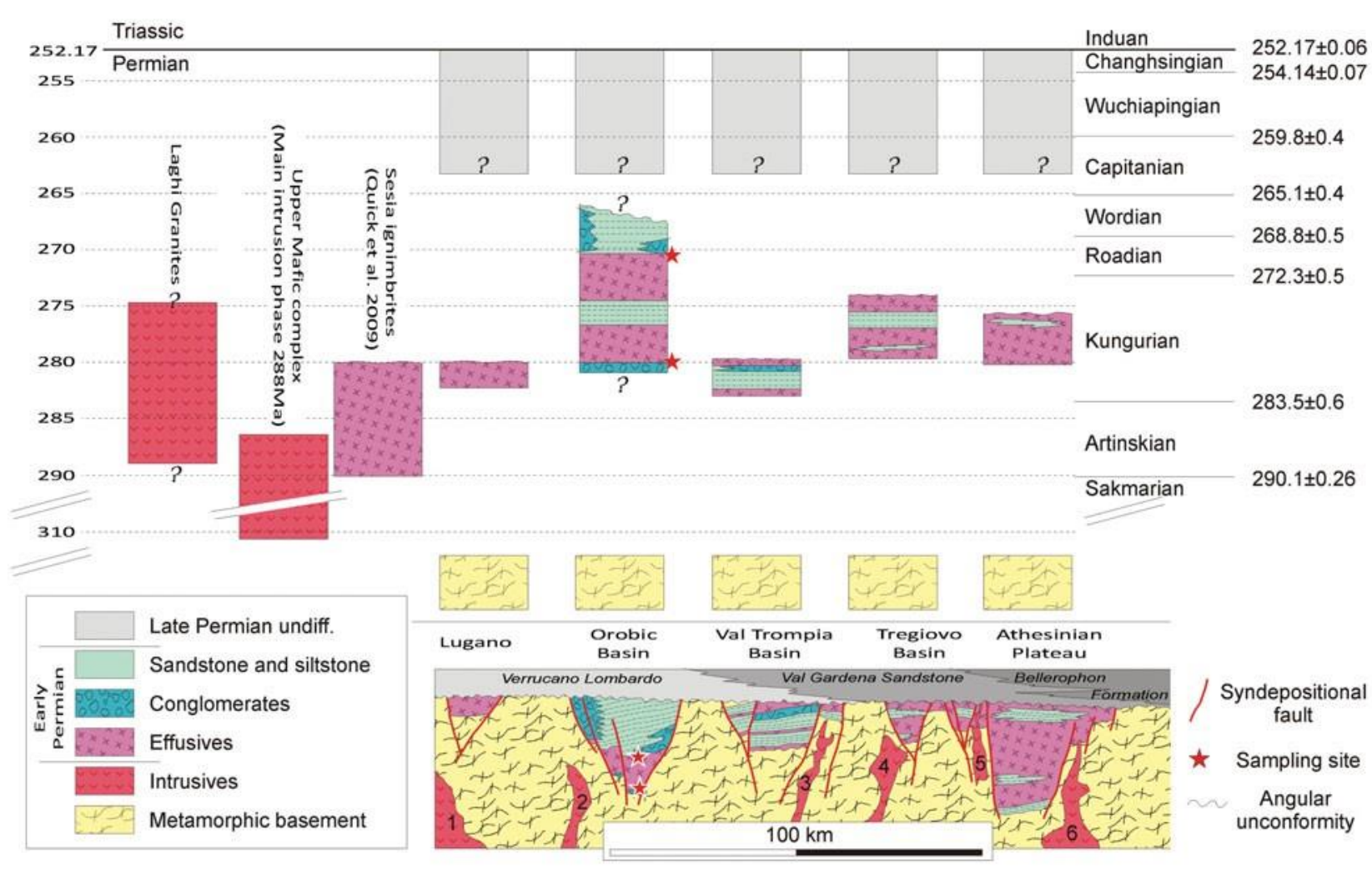

Figure 8. (Colour online) Schematic cross-section (below) and chronostratigraphic distribution (above) of the succession of the different Permian basins in the Southern Alps, along an approximately W-E-oriented section. In the simplified basement the position of major Permian intrusive bodies is sketched (1 - Laghi Granites; 2 - Val Biandino: 3 - Navazze; 4 - M. Sabion/M. Croce; 5 Terlano; 6 - Cima d'Asta). The geographic distribution of the different basins is modified from Cassinis et al. (1988), Schaltegger \& Brack (2007) and Marocchi et al. (2008). The age of the intrusive and effusive rocks in the west (Sesia Ignimbrites, Laghi Granites and Upper Mafic Complex) are from different authors (mainly Quick et al. 2009; Peressini et al. 2007 and references therein). The age distribution of the succession of the Permian basins in the chronostratigraphic chart is from the different authors mentioned in the text. The two red stars in the Orobic Basin indicate the position of the studied samples: VZ1 and VZ3 at the base and LG4 and LG5 at the top.

In this latter case, the expected consequence is an older average age with respect to the real age represented by the youngest population of zircons in the sample, with the risk of underestimating the duration of the volcanic event. Considering the relatively narrow range of ages for the different zircon populations, we think that this point is extremely critical in order to support reliable correlations of ages from different basins. 
The different durations of volcanic events in the different basins of the Southern Alps, documented by the published geochronological data, support a diachronous volcanic activity which lasted about $15 \mathrm{Ma}$. To precisely discriminate the chronological correlations among the different basins good-quality data (i.e. with reduced errors) are thus required coupled with a critical evaluation of the results. Our data suggest that: (1) a detailed discussion on the ages should be performed on each analysed sample (both considering data from a single sample and in comparison with samples with known relative ages) in order to exactly quantify the precise duration of volcanism in each basin before attempting a reliable correlation, and (2) a significant number of analyses with a known stratigraphic distribution can strongly improve any age interpretation. In the specific case study, the geological setting is further complicated by the strike-slip origin of the Permian basins of the Southern Alps (e.g. Cadel et al. 1997; Schaltegger \& Brack, 2007), which could have favoured a time-transgressive development of the Permian basins of the Southern Alps.

The age of the volcanic activity can be compared with that of the Lower Permian intrusive bodies that are commonly exposed in the Western Southern Alps. In the Sesia Valley, volcanic activity occurred between about $290 \mathrm{Ma}$ and 282 Ma (Fig. 8) (Quick et al. 2009). The older age is very similar to the age of the upper Mafic Complex in the Ivrea Verbano Zone, where the intrusion of mantle-derived magma culminated about $288 \mathrm{Ma}$ (Peressini et al. 2007).

The end of the major volcanic activity in the Sesia Valley (Quick et al. 2009) is close to that obtained for the basal tuff layers $(279 \pm 3 \mathrm{Ma})$ of the Orobic Basin. The volcanic activity and formation of the large granitic plutons of the 'Graniti dei Laghi' ended around $281 \mathrm{Ma}$ (Schaltegger \& Brack, 2007) even if questionable slightly younger ages based on $\mathrm{Rb}-\mathrm{Sr}$ geochronology (281 Ma to about $275 \mathrm{Ma}$ ) are indicated (Hunziker \& Zingg, 1980). Ages down to $275 \pm 4 \mathrm{Ma}$ were also measured for the aplitic granites intruding the volcanic rocks in the upper Valle Mosso (Quick et al. 2009). The end of the major volcanic activity in the Sesia Valley is thus close to the beginning of deposition of the Cabianca Volcanite and of the other volcanic rocks of the Southern Alps (Schaltegger \& Brack, 2007; Marocchi et al. 2008). The latest magmatic events in the Sesia Valley, however, partially overlap with the termination of the magmatic activity in the Orobic Basin.

\section{Conclusions}

Interpretation of the age (obtained with the U-Pb isotope method either with bulk, e.g. ID-TIMS, or microanalytical techniques, e.g. SIMS or LA-ICP-MS) of zircon populations from different samples of the same volcanic succession is frequently challenging owing to the presence of crystals of different ages. Whereas it is relatively simple to distinguish inherited cores or to define morphologically different populations, the situation is more complex when crystals are morphologically indistinguishable but the age distribution is larger than the uncertainty of the used analytical technique. Therefore, simple mean ages, although in some cases statistically correct, could give misleading results if not associated with a critical analysis of the data, able to take into account the relative ages of the analysed samples, possible late perturbation of the U-Pb system and date distributions of single crystals within each sample. Even if perturbation of the $\mathrm{U}-\mathrm{Pb}$ system is excluded, data interpretation may be extremely complex especially when mixing of antecrysts and autocrysts (sensu Miller et al. 2007), hardly identifiable within a single sample of a volcanic succession, occurs. Nevertheless, if a significant number of samples with defined stratigraphic position in the volcanic succession are considered, a reliable age definition should be suggested through the critical interpretation of the analytical data.

Analyses and comparisons of the age distribution of a significant group of samples from the same succession (where the relative age of the volcanic event is thus well known) are thus needed in order to improve and strengthen the interpretation of the age distribution in each sample. The possible presence of antecrysts could also be suggested by the lithological characteristics of the analysed samples (such as explosive ignimbritic flows, able to rip up older crystals during the magma ascent and eruption), which should be also taken into account during data discussion. Results from this study also indicate that to obtain reliable ages for a volcanic succession multiple samples with known relative ages (stratigraphic constraints) are required.

The critical interpretation of the analytical data from four samples (two at the base, two at the top of a volcanic unit), as well as their integration with the lithology and, in particular, their stratigraphic distribution highlighted the following points.

(1) The onset of the volcanic activity in the Orobic Basin was at about $280 \mathrm{Ma}$, based on the zircon age from the basal sample VZ1 (from an ash flow). The presence of antecrysts at about $291 \mathrm{Ma}$ in this sample probably record the onset of the volcanic activity in the Southern Alps, dated at $290 \mathrm{Ma}$ also by Quick et al. (2009). The beginning of the volcanic activity in the Orobic Basin is roughly coeval with that in the other basins of the Southern Alps, with the possible exception of the volcanism in the Collio Basin and in the Val Sesia succession, which are slightly older (Schaltegger \& Brack, 2007; Quick et al. 2009). In the overlying pyroclastic flows, the age distribution is complex in relation to the abundant xenocrystic/antecrystic material. However, we can confidently fix the end of the volcanic activity in the Orobic Basin at about $270 \mathrm{Ma}$, so that a roughly $10 \mathrm{Ma}$ duration of the 
volcanic activity is suggested. The volcanism in the Orobic Basin seems thus to end slightly later that in the other Early Permian basins (274.1 $\pm 1.6 \mathrm{Ma}$ is reported by Marocchi et al. 2008).

(2) The occurrence of xenocrystic zircons of about 300 Ma reflects a Carboniferous volcanic activity that is not documented by effusive products in the Orobic Basin. Such an activity is documented in other parts of the Southern Alps and may reflect the beginning of the Permian volcanism in the Southern Alps and surrounding domains (Sardinia, Corsica) and the late Carboniferous granulite-facies metamorphism in the Kinzigite Formation of the Ivrea-Verbano Zone (Peressini et al. 2007).

(3) Results from this work combined with the age distribution of the volcanic activity in the other Early Permian basins of the Southern Alps (Schaltegger \& Brack, 2007; Marocchi et al. 2008) suggest that the time distribution of the magmatism may be controlled by a time-transgressive beginning and end of the volcanic activity. This hypothesis should be considered carefully owing to the availability of ages obtained with different analytical methods in the different basins, so that new age data (critically interpreting the age results in the light of the stratigraphic distribution of the samples) are required to support any reliable interpretation. This probable shift in the age and volume of volcanic deposits can be explained by the dominance of strike-slip movements (Schaltegger \& Brack, 2007) along the faults that bound these basins, probably reflecting a major continental geodynamic event.

Acknowledgements. The comments of S. Sinigoi and of an anonymous reviewer are warmly acknowledged: their comments improved the original manuscript.

\section{Supplementary material}

To view supplementary material for this article, please visit http://dx.doi.org/10.1017/S0016756814000405.

\section{References}

Arthaud, F. \& MAtTE, P. 1977. Late Paleozoic strike-slip faulting in southern Europe and northern Africa: result of a right-lateral shear zone between the Appalachians and the Urals. Geological Society of America Bulletin 88, 130520.

Bargossi, G. M., Kloetzli, U. S., Mair, V., Marocchi, M. \& Morelli, C. 2004. The Lower Permian Athesian Volcanic Group (AVG) in the Adige Valley between Merano and Bolzano: a stratigraphic, petrographic and geochronological outline. In 32nd International Geological Congress, Florence, Scientific Sessions, Abstracts vol. 1, pp. 187.

Bargossi, G. M., MAIR, V., Morelli, C. \& SAPElZA, A. 2000. The Athesian Volcanic District (Bolzano-Trento area): a general outline. In Stratigraphy and Facies of the Permian Deposits between Eastern Lombardy and the Western Dolomites. Field trip guidebook. Continental Permian (eds G. Cassinis, L. Cortesogno, L. Gaggero, F. Massari, C. Neri, U. Nicosia \& P. Pittau), pp 21-4. International Congress Brescia, Italy, 15-25 September 1999. Pavia: Earth Science Department, Pavia University.

Bargossi, G. M., RotTura, A., Vernia, L., VisonÀ, D. \& TRANNE, C. A. 1998. Guida all'escursione sul distretto vulcanico atesino e sulle plutoniti di Bressanone-Chiusa e Cima d'Asta. Memorie Società Geologica Italiana 53, $23-41$.

BERRA, F. \& FELLETTI, F. 2011. Syndepositional tectonics recorded by soft-sediment deformation and liquefaction structures (continental Lower Permian sediments, Southern Alps, Northern Italy): stratigraphic significance. Sedimentary Geology 235, 249-63.

CADEL, G. 1986. Geology and uranium mineralization of the Collio Basin (Central Southern Alps, Italy). Uranium 2, $215-540$.

Cadel, G., Cosi, M., Pennacchioni, G. \& Spalla, M. I. 1996. A new map of the Permo-Carboniferous cover and Variscan metamorphic basement in the Central Orobic Alps, Southern Alps, Italy: structural and stratigraphical data. Memorie Scienze Geologiche di Padova 48, 1-53.

CASATI, P. \& GnacColini, M. 1967. Geologia delle Alpi Orobie occidentali. Rivista Italiana Paleontologia e Stratigrafia 73, 25-162.

Cassinis, G., Cortesogno, L., Gaggero, L., Massari, F., Neri, C., Nicosia, U. \& PitTaU, P. (eds). 2000. Stratigraphy and Facies of the Permian Deposits between Eastern Lombardy and the Western Dolomites. Field trip guidebook. Continental Permian, International Congress Brescia, Italy, 15-25 September 1999. Pavia: Earth Science Department, Pavia University, $157 \mathrm{pp}$.

Cassinis, G., Cortesogno, L., Gaggero, L., Perotti, C. \& Ronchi, A. 2007. Volcanic products from the Early Permian Collio Basin (southern Alps) and their geodynamic implications. Periodico di Mineralogia 76, 25-47.

Cassinis, G., Massari, F., Neri, C. \& Venturini, C. 1988. The continental Permian in the Southern Alps (Italy). A review. Zeitschrift fur Geologische Wissenschaften 16, 1117-26.

Corfu, F., Hanchar, J. M., Hoskin, P. W. O. \& Kinny, P. 2003. Atlas of zircon textures. In Zircon (eds J. M. Hanchar \& P. W. O. Hoskin), pp. 469-500. Reviews in Mineralogy and Geochemistry vol. 53.

De SitTer, L. U. \& DE SitTER-Koomans, C. M. 1949. Geology of the Bergamasc Alps, Lombardy, Italy. Leidse Geologische Mededelingen 14, 1-257. 
DoGloni, C. 1995. Geological remarks on the relationships between extension and convergent geodynamic settings. Tectonophysics 252, 253-67.

Ewing, T. A., Hermann, J. \& Rubatto, D. 2013. The robustness of the Zr-in-rutile and Ti-in-zircon thermometers during high-temperature metamorphism (Ivrea-Verbano Zone, northern Italy). Contributions to Mineralogy and Petrology 165, 757-79.

Gretter, N., Ronchi, A., LANGOne, A. \& Perotti, C. R. 2013. The transition between the two major Permian tectonostratigraphic cycles in the central Southern Alps: results from facies analysis and U/Pb geochronology. International Journal of Earth Sciences 102, 1181-202.

HARLOV, D. E. \& WIRTH, R. 2000. K-feldspar-quartz and K-feldspar-plagioclase phase boundary interactions in garnetorthopyroxene gneisses from the Val Strona di Omegna, Ivrea-Verbano Zone, northern Italy. Contributions to Mineralogy and Petrology 140, 148-62.

Horstwood, M. S. A., Foster, G. L., Parrish, R. R., Noble, S. R. \& Nowell, G. M. 2003. Common-Pb corrected in situ U-Pb accessory mineral geochronology by LA-MC-ICP-MS. Journal of Analytical Atomic Spectrometry 18, 837-46.

HUNZIKER, J. C. \& ZINGG, A. 1980. Lower Paleozoic amphibolite to granulite facies metamorphism in the IvreaZone (Southern Alps-Northern Italy). Schweizerische Mineralogische und Petrographische Mitteilungen 60, 181- 213.

Subcommission On Permian, Stratigraphy. International Permian Time Scale, 2013. Permophiles 57, 26.

Ketchum, J. W. F., Jackson, S. E., Culshaw, N. G. \& BARR, S. M. 2001. Depositional and tectonic setting of the Paleoproterozoic Lower Aillik Group, Makkovik Province, Canada: evolution of a passive margin-foredeep sequence based on petrochemistry and U-Pb (TIMS and LAM-ICP-MS) geochronology. Precambrian Research 105, 331-56.

LUDWIG, K. R. 2000. Isoplot-A Geochronological Toolkit for Microsoft Excel. Berkeley Geochronology Center, Special Publication No. 1a, 53 pp.

Malaveille, J., Guihot, P., LardeauX, J. M. \& Gardien, V. 1990. Collapse of thickened crust in the French Massif: Mont Pilat extensional shear zone and St. Etienne Late Carboniferous basin. Tectonophysics 177, 136-49.

Marocchi, M., Morelli, C., Mair, V., Klötzli, U. \& BArgossi, G. M. 2008. Evolution of large silicic magma systems: new U$\mathrm{Pb}$ Zircon data on the NW Permian Athesian Volcanic Group (Southern Alps, Italy). The Journal of Geology 116, 480-98.

Miller, J. S., MAtZel, J. P., Miller, C. F., Burgess, S. D. \& Miller, R. B. 2007. Zircon growth and recycling during the assembly of large, composite arc plutons. Journal of Volcanology and Geothermal Research 167, 282-99.

Muttoni, G., Kent, D. V., Garzanti, E., Brack, P., Abrahamsen, N. \& Gaetani, M. 2003. Early Permian Pangea 'B' to Late Permian Pangea 'A'. Earth and Planetary Science Letters 215, 379-94.

Peressini, G., QUick, J. E., Sinigoi, S., HofmAnN, A. W. \& FANNING, M. 2007. Duration of a large mafic intrusion and heat transfer in the lower crust: a SHRIMP U-Pb zircon study in the Ivrea-Verbano Zone (Western Alps, Italy). Journal of Petrology 48 , $1185-218$

Philippe, S., Villemaire, C., LANCElot, J. R., GiRoD, M. \& MerCADIER, H. 1987. Données minéralogiques et isotopiques sur deux gites hydrothermaux uranifères du bassin volcano-sédimentaire permien de Collio Orobico (Alpes Bergamasques): mise en évidence d'une phase de remobilisation crétacée. Bulletin de Minéralogie 110, 283-303.

Quick, J. E., Sinigoi, S., Peressini, G., Demarchi, G., Wooden, J. L. \& SbisÀ, A. 2009. Magmatic plumbing of a large Permian caldera exposed to a depth of $25 \mathrm{~km}$. Geology 37, 603-6.

SCHALTEGGER, U. \& BRACK, P. 2007. Crustal-scale magmatic system during intracontinental stike-slip tectonics: U, Pb and Hf isotopic constraints from Permian magmatic rocks of the Southern Alps. International Journal of Earth Sciences 96, $1131-51$.

Schaltegger, U., Fanning, C. M., GÜNTher, D., Maurin, J. C.|, Schulmann, K. \& Gebauer, D. 1999. Growth, annealing and recrystallization of zircon and preservation of monazite in high-grade metamorphism: conventional and in-situ U-Pb isotope, cathodoluminescence and microchemical evidence. Contributions to Mineralogy and Petrology 134, 186-201.

Siletto, G. B., Spalla, M. I., Tunesi, A., LardeauX, J. M. \& Colombo, A. 1993. Pre-Alpine structural and metamorphic histories in the Orobic Southern Alps, Italy. In Pre-Mesozoic Geology in the Alps (eds J. F. Von Raumer \& F. Neubauer), pp. 585-98. Heidelberg: SpringerVerlag.

SinigoI, S., Quick, J. E., Demarchi, G. \& KloEZli, U. 2011. The role of crustal fertility in the generation of large silicic magmatic systems triggered by intrusion of mantle magma in the deep crust. Contribution to Mineralogy and Petrology 162, 691-707.

VAn Achterbergh, E., RyAn, C. G., JACKSON, S. E. \& Griffin, W. 2001. Data reduction software for LA-ICPMS. In LaserAblation-ICPMSintheEarthSciences (ed. P. Sylvester), pp. 239-43. Mineralogical Association of Canada, vol. 29.

VAVRA, G., SCHMID, R. \& GEBAUER, D. 1999. Internal morphology, habit and U-Th-Pb microanalysis of amphibolite-togranulite facies zircons: geochronology of the Ivrea Zone (Southern Alps). ContributionstoMineralogy and Petrology 134, 380-404.

Wiedenbeck, M., Alle, P., Corfu, F., Griffin, W. L., Meier, M., Oberli, F., Quadt, A. V., Roddick, J. C. \& Spiegel, W. 1995. Three natural zircon standards for U-Th-Pb, Lu-Hf, trace element and REE analyses. Geostandards Newsletter 19, $1-24$.

WinTERER, E. L. \& Bosellini, A. 1981. Subsidence and sedimentation on Jurassic passive continental margin, Southern. Alps, Italy. American Association of Petroleum Geologists Bulletin 65, 394-421. 